http://dx.doi.org/10.5597/lajam00168

\title{
A NEW SKIN BIOPSY SYSTEM FOR USE WITH SMALL CETACEANS
}

\author{
Haydeé A. Cunha ${ }^{1,2,}$; Alexandre F. Azevedo ${ }^{1}$ and José Lailson-Brito, Jr. ${ }^{1}$
}

In the last several decades, genetic analyses have become invaluable tools for taxonomists and population biologists (Avise, 2004). Sampling tissue from live wild animals, including cetaceans, has proven vital to the understanding of many biological and ecological aspects (Lambertsen, 1987; Haig, 1998). Since the advent of the polymerase chain reaction (PCR, Saiki et al., 1985) genetic analyses require only a small amount of tissue, obtainable by non-destructive sampling. Sampling of tissues from live animals can be conducted during the manipulation of captured animals but, in the many cases where capture is unfeasible, or undesired, such sampling must rely on remote collection.

Biopsy darting is a remote sampling strategy that has been employed in several cetacean species, and has been recommended for genetic studies of natural populations, especially those where it can combine with field data on known individuals in monitored populations (Lambertsen, 1987; Hoelzel and Amos, 1988; Amos and Hoelzel, 1990; Hoelzel and Donovan, 1991). Animals that were biopsy sampled showed no permanent changes in patterns of spatial distribution nor avoidance to the vessel in any of the studies that used biopsy sampling (reviewed in Hoelzel and Donovan, 1991; Barrett-Lennard et al., 1996). Furthermore, the wound inflicted by the dart is minimal compared to injuries suffered by the animals in their natural habitats (Hoelzel and Donovan, 1991).

Remote biopsy sampling can be done with a collection device ('tip') attached to the front end of a dart (launched by crossbows, compressed air guns or modified veterinary rifles) or a pole. One tip, often used to sample tissue for contaminant analyses, is a metal cylinder with cutting edges and internal barbs, designed to retain a disc of skin plus a cylinder of blubber. A circular disc (or 'stop') around the base of the tip prevents penetration beyond the blubber and is responsible for the dart bouncing free after sample acquisition (Aguilar and Nadal, 1984; Lambertsen, 1987; Hoelzel and Amos, 1988; Amos and Hoelzel, 1990; Krützen et al., 2002). A second type of biopsy sampling device is designed for the sampling of skin only (for instance, the one presented by Harlin et al., 1999). Both sampling devices have proved to be effective for small cetaceans (Weller et al., 1997; Harlin et al., 1999; Möller et al., 2001; Krützen et al., 2002; Parsons et al., 2003; Fossi et al., 2004), and the method of Krützen et al. (2002) has already been applied to Sotalia (Caballero et al., 2007).
When sampling live animals, the least invasive system necessary should be preferred. Sampling with a pole is only feasible with species that bow-ride or allow very close approximation, and although poles seem to achieve lower impact sampling, they may be more stressful due to the need of closer approach and longer chasing time. Moreover, since individuals also differ in behaviour towards the boat, sampling with a pole will violate the often required assumption of equal probability of sampling. Due to all these factors, in most cases a projector, such as a crossbow, compressed air gun or modified veterinary rifle is required.

This paper reports the trials using widely used biopsy darting systems and the design of a novel system designed for small cetaceans. This novel system was developed to safely and effectively collect skin samples from Sotalia guianensis.

Since biopsy sampling would be conducted from small vessels in sheltered waters, we used a hand-held crossbow with 75lb of draw-weight (Barnett's Trident, <http:/ / www.barnettcrossbows.com>), adequate for hitting animals at short and medium distance (5 to 10m; Patenaude and White, 1995; Weller et al., 1997), and untethered floating darts. As tether lines may cause entanglements, they should only be used when dart retrieval is hampered by sea conditions or the size of the research vessel (Weinrich et al., 1991; BarrettLennard et al., 1996).

Before using any biopsy system on live animals, tests on fresh carcasses were conducted in order to achieve a proper evaluation of the characteristics of the biopsy system, while avoiding the risk of unnecessary harm to the animals (Patenaude and White, 1995). Three different collectors were tested. The first trials used a widely applied (Aguilar and Nadal, 1984; Hoelzel and Donovan, 1991; Barrett-Lennard et al., 1996; Weller et al., 1997; Krützen et al., 2002) skin-blubber cylindrical collector (8 $x 25 \mathrm{~mm}$, CETA-DART), with three inward facing internal barbs (Figure 1a). The tip was attached to a carbon fiber dart (CETA-DART), with a yellow cone-shaped floatation device that acts as a stop to inhibit further penetration while also improving visibility in water for dart recovery. This regular cylindrical tip was tested in two $S$. guianensis fresh carcasses (Code 2; Geraci and Lounsbury, 1993), shooting at various distances (from 2 to $5 \mathrm{~m}$ ), and aiming at the animals' flank, just below or slightly posterior to the dorsal fin. Shots were always at a perpendicular angle. 'Good hits' were defined as shots in which the dart

\footnotetext{
${ }^{1}$ Laboratório de Mamíferos Aquáticos e Bioindicadores, Faculdade de Oceanografia, Instituto de Geociências, Universidade do Estado do Rio de Janeiro, Rua São Francisco Xavier 524, Bloco E, Sala 4002, Maracanã, 20550-013, Rio de Janeiro, RJ, Brazil

${ }^{2}$ Laboratório de Biodiversidade Molecular, Departamento de Genética, Instituto de Biologia, Universidade Federal do Rio de Janeiro, Brazil "Corresponding author, e-mail: haydeecunha@ufrj.br
} 
bounced free after hitting the animal, and retained a sample. During these tests, the tip always remained attached to the animal and had to be forced off, and in $80 \%$ of shots it did not retain a sample. After limiting depth of penetration with a thick rubber hose around the tip, the system recoiled more successfully, but in $85 \%$ of the trials samples were not collected. Furthermore, the hose weight clearly affected the trajectory and speed of the dart, and good hits were only achieved when shooting at very close range - less than $2 \mathrm{~m}$. As Sotalia groups usually keep more than $5 \mathrm{~m}$ of distance from the vessel (H.A. Cunha, pers. obs.), this system could not be used for sampling live animals.
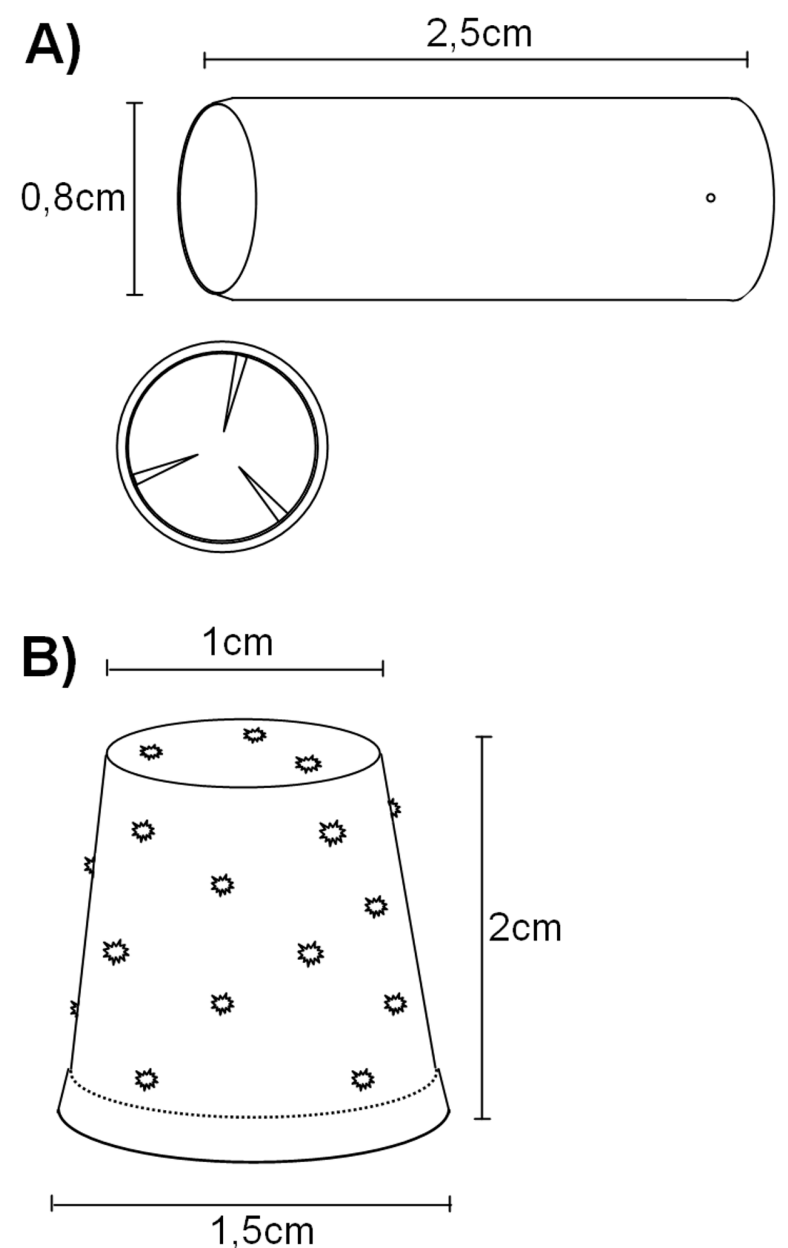

Figure 1. a) Standard (skin-blubber) biopsy tip. Inward facing internal barbs are shown in the front view. b) Skin-scratching biopsy tip. This tip can be assembled by making holes (from inside) in a metallic thimble, giving its external surface a 'grater-like' appearance.

The lack of recoil from the carcass in the system we initially tested could be due to the lack of crossbow power or to a depth of penetration where recoil power failed to remove the dart from the blubber layer. The second tip tested had a smaller diameter $(6 \mathrm{~mm})$ and was attached to a dart with reduced length and float material to improve speed. The collection tip had only two (instead of three) internal barbs. The customised system bounced free from carcasses more frequently ( $30 \%$ of hits) and even when shot at longer distances (up to $5 \mathrm{~m}$ ), but samples were retained only in $20 \%$ of hits. Nevertheless, the rate of tips that remained attached was still high $(70 \%)$, so the customised system was not tested on live animals.

We designed a novel biopsy system that used a scratching device (where penetration was not necessary), built to grasp skin pieces. The scratching tip consisted of a hollow metallic cone with a flat front end, and sharp edged holes over its surface (Figure 1b). The rear end of the tip was attached to the same darts that were used with the previous tips. Since the new tip was unable to penetrate deeper than the skin, and since the least powerful projector was being used, the new tip was considered safe to be directly tested on live animals.

The first attempts at biopsy sampling live S. guianensis took place in Baía de Guanabara, Rio de Janeiro State, Southeast Brazil, where a small population of resident dolphins has been the subject of a photo-identification study since 1995 (Azevedo et al., 2004, 2005, 2007, 2009). During fieldwork, a $4.2 \mathrm{~m}$ boat powered with a $25 \mathrm{HP}$ outboard engine was used. The archer was always located at the bow, and was never more than $1.5 \mathrm{~m}$ above sea surface. Biopsy tips were sterilised prior to fieldwork, through immersion in $70 \%$ ethanol, then in 100\% ethanol and flaming. They were kept in a case sterilised by UV irradiation (15min) and handled with fresh gloves. Tips were replaced following each hit. Biopsy sampling using the scratching tip was also successfully tested in two other S. guianensis populations: in Baía Norte, Santa Catarina State (South Brazil); and in the Cananéia Estuary, São Paulo State (Southeast Brazil).

Samples were obtained from every dolphin that was hit ( $\mathrm{n}=15$ ). Typically, three or more $1.0 \times 0.2 \mathrm{~cm}$ skin strips were collected from each dolphin in a single hit. Samples were stored in criotubes and kept in ice while in the field. They were later preserved either in liquid nitrogen, at room temperature in a salt saturated DMSO solution (Amos and Hoelzel, 1991) or in ethanol and kept at $-20^{\circ} \mathrm{C}$.

All biopsy samples provided high-quality DNA for genetic analyses (over 100ng/ $\mu \mathrm{L}$ ). A single strip of skin furnishes enough DNA for genetic analyses, such as molecular sexing (Cunha and Solé-Cava, 2007), mtDNA control region sequencing and genotyping for twelve microsatellite loci (Cunha et al., 2005; Cunha and Watts, 2007).

Short and long term responses to biopsy procedures were monitored. Both before and following the biopsy attempts, there were no changes in group structure, habitat use patterns or behaviour towards the boat. Several studies corroborate that biopsy darting has no long or even short-term negative effects on individuals or populations (Hoelzel and Donovan, 1991; Weinrich et al., 1991; Barret-Lennard et al., 1996; Weller et al., 1997; Krützen et al., 2002; Gorgone et al., 2008). The strongest direct response observed during this study was tail slapping, but it seemed to occur as a startle reaction to 
the sudden appearance of the dart, rather than to the hit itself, since it frequently happened when no animal was hit by the dart. Startle responses to biopsy darting were also observed in other species (Weinrich et al., 1991; Weinrich et al., 1992; Weller et al., 1997; Gauthier and Sears, 1999; Krützen et al., 2002; Parsons et al., 2003). The absence of strong reactions may be related to the brief duration of contact between our tip/dart set and the animals. Strong responses have been reported when darts stay attached to the animal or impact is too strong (either by power of projector or proximity to the target: Aguilar and Nadal, 1984; Weinrich et al., 1991; Weinrich et al., 1992; Gauthier and Sears, 1999; Bearzi, 2000; Krützen et al., 2002; Parsons et al., 2003). The only reported case of death during remote biopsy efforts was due to the penetration and retention of a skin-blubber dart in the dorsal muscle mass of a common dolphin (Delphinus delphis; Bearzi, 2000).

The wound inflicted by the scratching tip is minimal and superficial, suggesting it offered no harm to the animals' health. Since our scratching tip cannot penetrate deeper than the skin layer, it reduces considerably the risk of severely injuring the animals, as well as the likelihood of becoming a vector of infections. It has been demonstrated for example, in Tursiops truncatus, that wounds produced by the surgical removal of biopsies (3-5cm in diameter and $1 \mathrm{~cm}$ deep) heal in less than 42 days (Weller et al., 1997). In Tursiops spp., wounds produced by biopsy darting with cylindrical tips healed between 23 and 30 days (Krützen et al., 2002; Parsons et al., 2003). These observations suggest that the small scratches caused by our skin collector should heal within a very short time. However, an evaluation of healing could not be done, because scratches were not visible from the boat.

The skin biopsy system here described seems a good choice for use with small cetacean species, particularly when they can be approached by the research vessel. We strongly recommend their adoption by researchers interested in obtaining skin biopsies of wild-ranging individuals of S. guianensis for genetic analyses. The scratching tip offers advantages over the skin-blubber collector: it is safer because injuries are minimal and there is no risk that tip remains lodged in the animal; and it can be employed to many species without the need for adaptation. It is also efficient, since almost every hit is a 'good hit'. The efficiency is improved by the fact that the tip does not penetrate the animal, so the optimal angle of hit is acute in relation to the animal's longitudinal axis, instead of the perpendicular optimal hit of the skin-blubber tip (Barret-Lennard et al., 1996; Gauthier and Sears, 1999), which is more difficult to achieve. An additional advantage is that tips are easy and inexpensive to assemble: they can be prepared by making holes in metallic thimbles.

The scratching tip may be also adapted to fit a pole, for use with bow-riding species. It has been successfully applied to botos (Inia geoffrensis) that are hand fed, in three different sites in the Brazilian Amazon (V.M.F. da Silva, pers. comm.). In that latter case, botos approached close enough to be directly scratched, without the need of a projectile device.

A limitation of the described system is the collection range, since the $75 \mathrm{lb}$ crossbow is not powerful enough to reach distances greater than $8 \mathrm{~m}$. This can be solved by using a more powerful crossbow, or adapting the dart to fit a power-adjustable rifle. However, we advise that initial trials should be made with the least powerful projector, in order to minimise force of impact. In addition, when using higher power, some form of shock absorption may be necessary to alleviate the impact of perpendicular hits. Cylindrical skin-blubber tips require a high energy impact to guarantee that the dart will bounce free (Krützen et al., 2002), but for the scratching tip the minimum threshold will depend mostly on distance to the animals.

In the case of small cetaceans (such as Sotalia) we recommend: a) to sample at close range to improve hit/ miss ratio; b) to avoid sampling when the group is in very tight formation and surfacing unpredictably, to decrease the risk of unintentionally hitting fragile body sections; and c) to refrain from shooting at groups with mother/calf pairs, because hit impact may harm calves.

\section{Acknowledgements}

We are grateful to Finn Larsen, Susan Chivers and John Nicholas for their advisement and encouragement during the early stages of this work, and to Paulo A.C. Flores and Marcos C.O. Santos, for providing the logistical support for fieldwork in Baía Norte and Cananéia, respectively. We are indebted to Cristiano Lazoski for invaluable suggestions to an early draft. Mason Weinrich, Carlos Olavarría and an anonymous referee greatly improved the article. This work was supported by Universidade do Estado do Rio de Janeiro and Fundação de Amparo à Pesquisa do Estado do Rio de Janeiro (FAPERJ), and was part of HAC's M.Sc. thesis. HAC has a fellowship from FAPERJ (E26/100.209/2008) and AFA has a research grant from $\mathrm{CNPq}$ (grant no. 304826/2008-1). Biopsy samples were collected under permit 022/01/CMA/IBAMA.

\section{References}

Aguilar, A. And Nadal, J. (1984) Obtención de biopsias hipodérmicas de cetáceos en libertad. Investigación Pesquera 48(1): 23-29.

Amos, B. AND Hoelzel, A.R. (1990). DNA fingerprinting cetacean biopsy samples for individual identification. Report of the International Whaling Commission Special Issue 12: 79-85.

Amos, B. AND HoElzel, A.R. (1991). Long-term preservation of whale skin for DNA analysis. Report of the International Whaling Commission Special Issue 13: 99-103.

Avise, J.C. (2004) Molecular Markers, Natural History and Evolution. $2^{\mathrm{a}}$ ed. Chapman \& Hall, New York. 
Azevedo, A.F., Lailson-Brito, J.Jr., Cunha, H.A. and Van Sluys, M. (2004) A note on site fidelity of marine tucuxis (Sotalia fluviatilis) in Guanabara Bay, southeastern Brazil. Journal of Cetacean Research and Management 6(3): 265-268.

Azevedo, A.F., Viana, S.C., Oliveira, A.M. and Van Sluys, M. (2005) Group characteristics of marine tucuxis (Sotalia fluviatilis) in Guanabara Bay, south-eastern Brazil. Journal of the Marine Biological Association of the United Kingdom 85(1): 209-212. http://dx.doi.org/10.1017/S0025315405011082h

AzeVedo, A.F.; Oliveira, A.M.; Viana, S.C. and Van Sluys, M. (2007) Habitat use by marine tucuxis (Sotalia guianensis) in Guanabara Bay, south-eastern Brazil. Journal of the Marine Biological Association of the United Kingdom 87(1): 201-205. http:/ / dx.doi.org/10.1017/S0025315407054422

AzeVedo, A.F., LaILson-Brito, J.Jr., Dorneles, P.R., VAn Sluys, M., CunHA, H.A. AND Fragoso, A.B.L. (2009) Human-induced injuries to marine tucuxis (Sotalia guianensis) (Cetacea: Delphinidae) in Brazil. Marine Biodiversity Records 2: e22. http://dx.doi.org/ $10.1017 /$ S1755267208000262

BarRetT-LenNard, L.G., SMith, T.G. and ElLis, G.M. (1996) A cetacean biopsy system using lightweight pneumatic darts, and its effect on the behavior of killer whales. Marine Mammal Science 12(1): 14-27. http://dx.doi.org/10.1111/j.17487692.1996.tb00302.x

Bearzi, G. (2000) First report of a common dolphin (Delphinus delphis) death following penetration of a biopsy dart. Journal of Cetacean Research and Management 2(3): 217-221.

Caballero, S., Trujillo, F., Vianna, J.A., Barrios-Garrido, H., Montiel, M.G., Beltrán-Pedreros, S., Marmontel, M., Santos, M.C.O., Rossi-Santos, M., SANTOS, F.R. And BAKER, C.S. (2007) Taxonomic status of the genus Sotalia: Species level ranking for 'tucuxi' (Sotalia fluviatilis) and 'costero' (Sotalia guianensis) dolphins. Marine Mammal Science 23(2): 358-386. http:/ / dx.doi.org/10.1111/j.1748-7692.2007.00110.x

Cunha, H.A., Da Silva, V.M.F., Lailson-Brito, J.Jr., Santos, M.C.O., Flores, P.A.C., Martin, A.R., Azevedo, A.F., Fragoso, A.B.L., Zanelatto, R.C. AND SolÉ-CAVA, A.M. (2005) Riverine and marine ecotypes of Sotalia dolphins are different species. Marine Biology 148(2): 449-457. http://dx.doi.org/10.1007/s00227-005-0078-2

CunHA, H.A. AND Solé-CAvA, A.M. (2007) Molecular sexing of tucuxi dolphins (Sotalia guianensis and S. fluviatilis), using samples from biopsy darting and decomposed carcasses. Genetics and Molecular Biology 30(4): 11861188. http://dx.doi.org/10.1590/S1415-47572007000600025

CunHA, H.A. And WATTS, P.C. (2007) Twelve microsatellite loci for marine and riverine tucuxi dolphins (Sotalia guianensis and S. fluviatilis). Molecular Ecology Notes 7(6): 1229-1231. http:/ / dx.doi.org/10.1111/j.1471-8286.2007.01839.x

Fossi, M.C., Marsili, L., Lauriano, G., Fortuna, C., Canese, S., AnCorA, S., LeONZIO, C.; RomeO, T., Merino, R., ABAD, E. AND JiMÉnEZ, B. (2004) Assessment of toxicological status of a SW Mediterranean segment population of striped dolphin (Stenella coeruleoalba) using skin biopsy. Marine Environmental Research 58(2): 269-274. http://dx.doi.org/10.1016/j.marenvres.2004.03.070

GaUthiER, J. AND SeARs, R. (1999) Behavioral responses of four species of balaenopterid whales to biopsy sampling. Marine Mammal Science 15(1): 85-101. http://dx.doi.org/10.1111/ j.1748-7692.1999.tb00783.x

Geraci, J. R. AND Lounsbury, V.J. (1993) Marine Mammals Ashore: A Field Guide for Strandings. Texas A\&M Sea Grant.

Gorgone, A.M., HaAse, P.A., Griffith, E.S. and Hohn, A.A. (2008) Modeling response of target and nontarget dolphins to biopsy darting. Journal of Wildlife Management 72(4): 926-932. http:/ / dx.doi.org/10.2193/2007-202

HAIG, S.M. (1998) Molecular contributions to conservation. Ecology 79(2): 413-425. http://dx.doi.org/10.1890/00129658\%281998\%29079\%5B0413:MCTC\%5D2.0.CO;2

HARLIN, A.D., WÜRSIG, B., BAKER, C.S. AND MARKOWITZ, T.M. (1999) Skin swabbing for genetic analysis: applications to dusky dolphins (Lagenorhynchus obscurus). Marine Mammal Science 15(2): 409-425. http://dx.doi.org/10.1111/j.1748-7692.1999.tb00810.x

Hoelzel, A.R. AND Amos, W. (1988) DNA fingerprinting and 'scientific' whaling. Nature 333(6171): 305. http:/ / dx.doi.org/ $10.1038 / 333305 \mathrm{a} 0$

Hoelzel, A.R. and Donovan, G.P. (Eds) (1991) Genetic Ecology of Whales and Dolphins Report of the International Whaling Commission Special Issue 13. IWC, Cambridge.

KRÜTZEn, M., BarRÉ, L.M., Möller, L.M., Heithaus, M.R., SimmS, C. AND SHerwin, W.B. (2002) A biopsy system for small cetaceans: darting success and wound helaing in Tursiops spp. Marine Mammal Science 18(4): 863-878. http://dx.doi.org/ 10.1111/j.1748-7692.2002.tb01078.x

LAMBERTSEN, R.H. (1987) A biopsy system for large whales and its use for cytogenetics. Journal of Mammalogy 68(2): 443-445. http:/ / dx.doi.org/10.2307/1381495

Möller, L.M., Beheregaray, L.B., Harcourt, R.G. and KRÜtzen, M. (2001) Alliance membership and kinship in wild male bottlenose dolphins (Tursiops aduncus) of southeastern Australia. Proceedings of the Royal Society of London Series B-Biological Sciences 268(1479): 1941-1947. http:/ / dx.doi.org/10.1098/rspb.2001.1756

Parsons, K.M., Durban, J.W. and Claridge, D.E. (2003) Comparing two alternative methods for sampling small cetaceans for molecular analysis. Marine Mammal Science 19(1): 224-231. http://dx.doi.org/10.1111/j.1748-7692.2003.tb01104.x

Patenaude, N.J. And White, B.N. (1995) Skin biopsy sampling of beluga whale carcasses: assessment of biopsy darting factors for minimal wounding and effective sample retrieval. Marine Mammal Science 11(2): 163-171. http://dx.doi.org/10.1111/ j.1748-7692.1995.tb00515.x

Saiki, R.K., Scharf, S., Faloona, F., Mullis, K.B., Horn, G.T., ERLICH, H.A. AND ARNHEIM N. (1985) Enzymatic amplification of â-globin genomic sequences and restriction site analysis for diagnosis of sickle cell anemia. Science 230(4732): 1350-1354. http://dx.doi.org/10.1126/science.2999980

WeInRICH, M.T., LAMBERTSEN, R.H., BAKER, C.S., SCHILLING, M.R. AND BELT, C.R. (1991) Behavioural responses of humpback whales (Megaptera novaeangliae) in the Southern Gulf of Maine to biopsy sampling. Report of the International Whaling Commission Special Issue 13: 91-98.

Weinrich, M.T., LAmberTson, R.H., Belt, C.R., SChILLING, M.R IKEN, H.J. AND SYRJALA, S.E. (1992) Behavioral reactions of humpback whales Megaptera novaeangliae to biopsy procedures. Fishery Bulletin 90(3): 588-598

Weller, D.W., COCKCROFT, V.G., WÜRSIG, B., LYNN, S.K. AND FERTL, D. (1997) Behavioral responses of bottlenose dolphins to remote biopsy sampling and observations of surgical biopsy wound healing. Aquatic Mammals 23(1): 49-58.

Received on 3 March 2009. Accepted on 13 June 2010. Managed by Carlos Olavarría. 